\title{
The unpaid donation of blood and altruism: a comment on Keown
}

\author{
Hugh V McLachlan Glasgow Caledonian University, Glasgow
}

\begin{abstract}
In line with article 3.4 of EC directive 89/381, Keown has presented an ethical case in support of the policy of voluntary, unpaid donation of blood. Although no doubt is cast on the desirability of the policy, that part of Keown's argument which pertains to the suggested laudability of altruism and of its encouragment by social policy is examined and shown to be dubious.

(Fournal of Medical Ethics 1998;24:252-254)
\end{abstract}

Keywords: Altruism; blood; donation; paid/unpaid; European Community directive 98/381

\section{Introduction}

Keown presents "an ethical case in favour of voluntary, unpaid donation [of blood and plasma]. It comprises five arguments". ${ }^{1}$ I shall discuss and strongly disagree with one of these arguments, the one about "altruism and social solidarity". Keown's claim that: "There would appear to be at least five sound reasons for discouraging, as a matter of social policy, paid donation of blood and plasma" is, I shall suggest, a dubious one. ${ }^{2}$

That there is a sound non-ethical case for favouring this system of blood and plasma collection - it is, for instance, cheaper for the taxpayer and likely to be safer than alternative systems and that this case suffices to establish a preference for it I do not doubt.

\section{Keown on altruism and blood donation Keown writes:}

"A major argument for exclusive reliance on unpaid donation is that, unlike paid donation, it promotes altruism and social solidarity. Titmuss, in his landmark study of blood donation and social policy, wrote that his study was essentially about 'the role of altruism in modern society'."3

Keown agrees with Singer's view “... that altruism is a virtue which increases the more it is practised" and says that: "The old maxim that an act tends to become a habit and a habit tends to form a character seems apt." ${ }^{4}$
The following quotation from Murray $\tilde{\rho}_{\mathrm{is}}$ presented with approval by Keown:

" Gifts to strangers affirm the solidarity of the community over and above the depersonalizi隹g, alienating forces of mass society and market ribations. They signal that self-interest is not the ondy significant human motivation. And they expross the moral belief that it is good to minister to fundamental human needs, needs for food, hedth care and shelter... . These universal needs irrecably tie us together in a community of needs, with a shared desire to satisfy them, and see them satisfied in others'." 5

According to Keown:

"An individual who acts altruistically thereby to develop an altruistic character becomes more rather than less disposed to $\mathbb{R} c t$ altruistically. It is obvious too that the same hofds in relation to the person who performs selfish aets: the person who (say) steals other peop孯's property tends thereby to develop a rapacious character... . In short, acts of altruism promiste further acts of altruism in that they tend $\vec{\Phi}_{\text {to }}$ reinforce altruistic dispositions."

\section{Against altruism or, at least, the encouragement of it}

Keown states or seems to imply something like fhe following propositions:

(i) Non-paid voluntary blood donation is, becaQ̊se it is voluntary and unpaid, altruistic; (ii) Altruism in general is a particularly ${ }_{\text {thing; and }}$
the

(iii) Social policy should be formulated to enco age altruism because altruism is a particulâtly good thing.

Each of the claims is contentious.

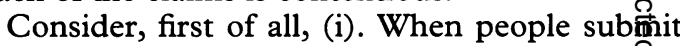
contributions to, say, the fournal of Medical Eth? their actions are voluntary and unpaid: does it follow from this that they are altruistic? I do not see 
that it does. The writing and offering for consideration for publication of such papers might be but need not be altruistic.

Not all actions are either done for the sake of money or are altruistic. Some are both. Some are neither. Those which are altruistic are not always morally more laudable than the rest. Even when actions are morally laudable, it is not always appropriate that, through the formulation of social policy, they and/or the motivation which provoked them be given encouragement by the state.

In relation to (ii) and (iii), consider the following passage.

"The child sat by and watched its progress with a troubled mind. Regardless of the run of luck, and mindful only of the desperate passion which had its hold upon her grandfather, losses and gains were to her alike. Exulting in some brief triumph, or cast down by a defeat, there he sat so wild and restless, so feverishly and intensely anxious, so terribly eager, so ravenous for the paltry stakes, that she could have almost borne better to see him dead. And yet she was the innocent cause of all this torture, and he, gambling with such a savage thirst for gain as the most insatiable gambler never felt, had not one selfish thought!"7

The grandfather of little Nell, from The Old Curiosity Shop here, has not one selfish thought. He is an altruist. He is gambling - for money, of course, but - for the sake of his granddaughter. His actions, although altruistic - the prelude, he hopes, to the gift to little Nell of the money thereby gained - are wrong. They are vicious in the sense of being in the character of a vice. It is certain that his altruistic action should not be encouraged! The less this particular manifestation of altruism is practised the better.

Keown is making and suggesting false dichotomies. Actions can be altruistic and wrong and worthy of discouragement. They can also be altruistic and done for money. Furthermore, merely because an action was done for the sake of money does not mean nor imply that the action is wrong nor, necessarily, in any respect morally dubious even although such actions can be, like some particular altruistic actions, very wrong. They can also be worthy of discouragement by the state, sometimes, as well as by private moral agents.

It is manifest that good outcomes can result from the self-interested pursuit of money. For instance, Dickens's The Old Curiosity Shop, which was written for money, is, even allowing for the appalling over-sentimentalisation of Nell's death, more worthy in all respects which I can think of than many other examples of prose which were not written for monetary gain, including the one you are now reading, and than many which were written, let us allow, for altruistic reasons such as, say, The Communist Manifesto and Titmuss's The Gift Relationship.

Altruism can and often does produce havoc. Guy Fawkes and the other wretched gunpowder conspirators were not motivated by monetary considerations. They would probably have done more good and risked the production of less harm if they had been. Often, altruism results in extremely wicked actions because people can, wrongly, be prepared to do for other people things which they would, rightly, be too ashamed to do solely for themselves. The recent suicide bombers in Israel, who killed over a dozen bystanders in a crowded market-place and injured many more were not - or possibly were not - lacking in altruism. However, altruism is no more inherently good than the pursuit of monetary gain is inherently bad. Notice too that it is to paid policemen and paid soldiers rather than to enthusiastic and altruistic amateurs that we look for protection from such violent and, often, woefully non-selfregarding people.

Some people might want to say here - although I for one can resist this temptation - that such seemingly altruistic acts as terroristic ones are not, when properly interpreted, truly altruistic at all but, of course, this would invite the response that the same thing could be said about unpaid blood donation.

Altruism can be good in some contexts and can be bad in others. It can have good effects as well as bad effects. It can be done for good motives as well as bad ones: altruistic motives are not always good; self-interested motives - and these are not always "selfish" ones - are not always bad. Furthermore, there is no convincing a priori case for expecting altruistic motives and actions to be good nor self-interested ones to be bad. Social policy should be no more geared in general towards the fostering of altruism rather than selfinterest, including that which is related to pecuniary gain.

Suppose, for instance, that you were to marry someone purely for altruistic reasons. Such an action with such a motivation would be rotten. It would be appallingly bad. It would, I think, be even worse than marrying someone purely for financial gain.

\section{Conclusion}

I do not know whether altruism in the abstract and in general can be nurtured - perhaps this is a psychological rather than a philosophical issue but, if it can be, I see - as a philosophico-ethical 
matter - no reason why such altruism rather than, say, the pursuit of self-interested monetary gain should be encouraged by the state nor by any other agency nor person.

If the altruistic donation of blood is such an unreservedly good thing, then why stop at the donation of a pint? Why not give two pints, or three, or ...? Why not, in an act of altruistic suicide, donate the whole lot? The answer, of course, is that altruism untempered is not a good thing. Altruism is a good thing only in the context of, amongst other things, the pursuit of selfinterest and the acquisition of money.

Vitamin C can be good for us. I do not think that it necessarily follows from that that politicians and/or "social-policy makers" should encourage us to consume vitamin C. Manifestly, it does not follow that they should encourage us not to eat food which does not contain vitamin C. They should not encourage us to eat only vitamin C.

Analogously, to lead a good life, in all senses of "goodness", we need a healthy, balanced diet of motives and actions, which includes altruistic and non-altruistic actions, self-interested and n尺ึself-interested actions, actions performed 电or money and actions which are not performed f్for money and ones which are a combination of two or more of these sorts. The idea that "so g.jal policy" should be formulated in order to encōerage one rather than another of these types $\overline{\bar{O}}_{\mathrm{O}}$ motives and actions is misguided. It seems to to be misplaced sentimentality, masqueradingos moral sensitivity.

Hugh VMcLachlan, MA, PhD, is Lecturer in Socioblogy, Department of Social Sciences, Glasgow Caleggonian University, Glasgow.

\section{References}

1 Keown J. The gift of blood in Europe: an ethical defence of directive 89/381. Fournal of Medical Ethics 1997; 23: 96-109J

2 See reference 1: 99

3 See reference 1: 96.

4 See reference 1: $97-98$.

5 See reference 1: 97.

6 See reference 1: 98 .

7 Dickens C. The old curiosity shop. London and Glas Collins, 1992: 213.
๘)

$\vec{\circ}$

\section{News and notes}

\section{IVth World Congress of IAB}

The IVth World Congress of the International Association of Bioethics, Global Bioethics: East and West, South and North, will be held from 4 - 6 November this year in Ichigaya, Tokyo, Japan. Up to date information and call for abstracts will be available on the Internet through: http://www.uclan.ac.facs/ethics/iab.htm http:// www.biol.tsukuba.ac.jp/ macer/IAB4.html
Also, for information, contact: Professor Hyakudai Sakamoto, President, The East Asian Association fo Bioethics, c/o University Research Center, Nihon? University, 4-8-24 Kudan-Minami, Chiyoda-ku, Tokyo 102, Japan. Fax: int +81 352758 326; e-mail. sakamoto@chs.nihon-u.ac.jp 